\title{
Ganti Rugi Perbuatan Melawan Hukum dalam Gugatan Perwakilan Kelompok di Indonesia
}

\author{
Erna Widjajati \\ Fakultas Hukum Universitas Krisnadwipayana \\ Jalan Jatiwaringin, Jakarta Timur \\ widjajatierna@yahoo.com
}

\begin{abstract}
The problem reviewed in the research was the procedure of compensation on tort in representation claim. This research was juridical normative research. The legal material used in this research was primary legal material in the form of legislation and court decisions, and secondary legal material. The legal material was analyzed qualitatively. This research concluded that if the compensation claim was granted, the judge had decided the amount of compensation in detail, group determination, the mechanism of compensation distribution and steps must be taken by the group representative as well as the obligation to conduct the notification.
\end{abstract}

Key words : Group representation claim, compensation, tort

\begin{abstract}
Abstrak
Permasalahan yang dikaji dalam penelitian adalah prosedur distribusi ganti rugi perbuatan melawan hukum dalam gugatan perwakilan. Penelitian ini adalah penelitian yuridis normatif. Bahan hukum yang dipergunakan dalam penelitian ini berupa bahan hukum primer dalam bentuk peraturan perundang-undangan dan putusan pengadilan, dan bahan hukum sekunder. Bahan hukum tersebut dianalisis secara kualitatif. Penelitian ini menyimpulkan bahwa jika tuntutan ganti kerugian dikabulkan, hakim wajib memutuskan jumlah ganti rugi secara rinci, penentuan kelompok, mekanisme pendistribusian ganti rugi dan langkah-langkah yang wajib ditempuh oleh wakil kelompok seperti halnya kewajiban melakukan pemberitahuan atau notifikasi.
\end{abstract}

Kata kunci : Gugatan perwakilan kelompok, ganti rugi, perbuatan melawan hukum 


\section{Pendahuluan}

Dalam perkembangan hukum acara perdata, di samping gugatan perdata konvensional itu, lahir apa yang dinamakan gugatan perwakilan kelompok (class action). Gugatan perwakilan kelompok mengacu kepada suatu gugatan perwakilan oleh seseorang untuk kepentingan dirinya sendiri dan kepentingan kelompok dalam jumlah yang besar (plaintiff class action). Gugatan ini juga berlaku bagi suatu penerima gugatan secara perwakilan terhadap seseorang atau lebih yang ditunjuk untuk membela kepentingan diri sendiri dan kelompok dalam jumlah yang besar (defendant class action).

Gugatan perwakilan kelompok merupakan prosedur beracara dalam suatu perkara perdata yang memberikan hak beracara terhadap satu orang atau lebih bertindak sebagai penggugat untuk memperjuangkan kepentingan para penggugat sendiri sekaligus mewakili kepentingan orang banyak yang mengalami kesamaan penderitaan atau kepentingan. ${ }^{1}$ Penggunaan gugatan perwakilan memiliki legitimasi sebagai gugatan yang melibatkan orang banyak yang mengalami penderitaan atau kerugian. Dengan adanya gugatan perwakilan ini, maka persoalan ketidakpraktisan dan ketidakefisiensian gugatan konvensional dapat diatasi. ${ }^{2}$ Lembaga gugatan perwakilan kelompok ini merupakan dimensi baru dalam hukum acara perdata Indonesia, namun baik dari segi konsep maupun implementasinya belum begitu jelas, dan masih menimbulkan sejumlah permasalahan.

Mengingat masih belum jelasnya konsep tersebut, seringkali praktisi hukum di Indonesia mencampuradukkan pengertian atau konsep gugatan perwakilan kelompok dengan konsep hak gugat (standing). Padahal keduanya memiliki perbedaan konsep yang mendasar. Hak gugat ini merupakan akses perorangan maupun kelompok atau organisasi yang bertindak untuk dan atas nama kepentingan publik maupun kepentingan lingkungan hidup ke pengadilan sebagai penggugat. Hak gugat organisasi lingkungan hidup merupakan salah satu bagian dari standing law. ${ }^{3}$ Dengan demikian, sesungguhnya apa yang dilakukan oleh Yayasan Wahana Lingkungan selama dalam memberikan advokasi lingkungan,

${ }^{1}$ Di sini satu orang atau lebih yang tampil sebagai penggugat disebut wakil kelas (class representative) dan sejumlah orang banyak yang diwakili yang disebut class members.

${ }^{2}$ Mas Achmad Santoso, et al, Pedoman Penggunaan Gugatan Perwakilan, ICEL - PIAC - YLBHI, Jakarta, 1999 , hlm. 1

${ }^{3}$ Susanti Adi Nugroho, Pedoman Prosedur Gugatan Perwakilan Kelompok (Class Actions) di Indonesia, Kapuslitbang Hukum dan Peradilan Mahkamah Agung RI, Jakarta, tanpa tahun, hlm. 9. 
tidak termasuk dalam kategori gugatan perwakilan kelompok, tetapi sebagai pelaksanaan dari hak gugat yang diakui UUPLH. Pasal 38 ayat (1) UUPLH sendiri menyatakan bahwa dalam rangka pelaksanaan tanggung jawab pengelolaan lingkungan sesuai dengan pola kemitraan, organisasi lingkungan hidup berhak mengajukan gugatan untuk kepentingan pelestarian fungsi lingkungan hidup.

Walaupun telah ada pengakuan keberadaan gugatan perwakilan kelompok dalam beberapa peraturan perundang-undangan, namun sampai saat ini belum ada peraturan perundangan yang mengatur hukum acaranya. Untuk mengisi kekosongan hukum acara tersebut, Mahkamah Agung telah mengeluarkan Peraturan Mahkamah Agung Republik Indonesia Nomor 1 Tahun 2002 tentang Gugatan Perwakilan Kelompok. Dari sisi hukum acara yang berlaku di Indonesia, gugatan perwakilan kelompok menimbulkan masalah yang berkaitan dengan legitima persona standi in judicio ${ }^{4}$ dari para pihak yang maju ke pengadilan.

Hukum acara perdata yang berlaku sekarang ini, memang belum mengatur gugatan perwakilan kelompok, padahal dalam praktik pengadilan, gugatan perwakilan kelompok makin meningkat. Oleh karena itu, ada kebutuhan akan suatu aturan mengenai pelaksanaan gugatan perwakilan kelompok. Untuk mengatasi hal tersebut, Mahkamah Agung memang telah mengeluarkan PERMA Nomor 1 Tahun 2002, tetapi ini hanya merupakan praktik jalan pintas untuk mengisi kekosongan hukum dalam memenuhi kebutuhan praktik peradilan. ${ }^{5}$

Keberadaan PERMA Nomor 1 Tahun 2002 dari segi yuridisnya sendiri masih menimbulkan permasalahan. Bentuk peraturan perundang-undangan seperti ini tidak dikenal dalam tata urutan peraturan perundang-undangan Indonesia. Kekuatan hukumnya masih dipertanyakan. Apabila terjadi pertentangan antara PERMA dan HIR atau RBG, mana yang harus didahulukan? Secara yuridis formal, PERMA itu bukan lex specialis dari HIR atau RBG, karena keduanya tidak sederajat. Di lain pihak PERMA ini sendiri menjadikan HIR atau RBG sebagai dasarnya. Substansi PERMA tersebut, pada dasarnya hanya berisi prosedur saja. Banyak hal yang belum diatur baik oleh PERMA maupun peraturan perundang-undangan lainnya, misalnya bagaimana cara penentuan ganti rugi. Jika gugatan tersebut diterima dan berkekuatan hukum yang tetap, timbul persoalan baru berkaitan

\footnotetext{
${ }^{4}$ Mempunyai kewenangan untuk bertindak di depan pengadilan selaku pihak.

${ }^{5}$ Paulus Effendie Lotulung, "Keynote Speech", Lokakarya Acara Gugatan Perwakilan Kelompok (Class Action), Forum Kajian Hukum Fakultas Hukum Universitas Pakuan - Lembaga Penelitian dan Pertimbangan Hukum Administrasi Negara, Bogor, 27 Juli 2002, hlm. 1 - 5
} 
dengan cara pendistribusian ganti rugi tersebut. Kemudian timbul persoalan terkait dengan persoalan jika ada yang menerima dan menolak putusan pengadilan.

\section{Rumusan Masalah}

Pertama, apakah tujuan gugatan perwakilan kelompok? Kedua, bagaimanakah distribusi ganti rugi dalam perbuatan melawan hukum melalui gugatan perwakilan kelompok di Indonesia?

\section{Tujuan Penelitian}

Pertama, untuk mengetahui tujuan gugatan perwakilan kelompok. Kedua, untuk mendapatkan pemahaman yang lebih mendalam mengenai distribusi ganti rugi dalam perbuatan melawan hukum melalui gugatan perwakilan kelompok di Indonesia?

\section{Metode Penelitian}

Penelitian ini bersifat kualitatif ${ }^{6}$ dengan menggunakan pendekatan yuridis normatif, yuridis empiris dan komparatif. Seluruh data diambil dari bahan-bahan kepustakaan yang berkaitan dengan objek penelitian. Setelah data terkumpul, kemudian dikaji dan dianalisis dengan menggunakan kerangka teori yang digunakan dalam penelitian ini, selanjutnya dituangkan kedalam konstruksi pembahasan yang logis, sistematis dan komprehensif.

Pengumpulan bahan hukum primer dilakukan dengan menelusuri dan mengkaji norma yang terdapat dalam peraturan perundang-undangan. ${ }^{7}$ Selain kedua bahan hukum tersebut, juga dikenal bahan hukum tersier sebagai pelengkap dari bahan hukum primer dan sekunder. Bahan hukum tersier, berbentuk kamus hukum serta ensiklopedi ${ }^{8}$ yang berkaitan dengan bidang hukum.

Data sekunder yang diperoleh adalah bahan hukum primer berbentuk peraturan perundang-undangan yang berlaku di Indonesia. Peraturan itu diantaranya adalah Undang-Undang No. 23 Tahun 1997 tentang Pengelolaan Lingkungan Hidup dan Undang-Undang No. 8 Tahun 1999 tentang Perlindungan Konsumen, serta Undang-

\footnotetext{
${ }^{6}$ Metodologi kualitatif; sebagai prosedur penelitian yang menghasilkan data data diskriptif berupa kata-kata tertulis atau lisan.

${ }^{7}$ C.F.G. Sunaryati Hartono, Penelitian Hukum di Indonesia pada Akhir Abad ke-20, Alumni, Bandung, 1994, hlm. 148

${ }^{8}$ Ibid., hlm. 15
} 
Undang No. 41 Tahun 1999 tentang Kehutanan. Ketiga undang-undang itu telah mengatur mengenai class action, sehingga menjadi dasar hukum bagi class action di Indonesia. Tahun 2002 diterbitkan Peraturan Mahkamah Agung Republik Indonesia Nomor 1 Tahun 2002 tentang Acara Gugatan Perwakilan Kelompok. Selain ketiga undang-undang di atas, juga diperoleh putusan pengadilan baik di Indonesia maupun putusan pengadilan di berbagai negara. Putusan pengadilan tersebut mempunyai arti penting dalam penelitian hukum normatif ini, khususnya dalam melihat permasalahan hukum yang terjadi khususnya penerapan class action di Indonesia.

\section{Hasil dan Pembahasan}

\section{Tujuan Melakukan Gugatan Perwakilan Kelompok}

Prosedur gugatan perwakilan kelompok yang menggunakan pendekatan benefits and costs terdapat tiga tujuan utama yang dianggap sebagai keuntungan yang melekat pada gugatan perwakilan kelompok. Ketiga tujuan utama tersebut adalah judicial economy (efficiency), increased access to the courts (justice), dan modification of the behavior of actual or potential wrongdoers.

Pertama, ada penghematan biaya peradilan (judicial economy) jika digunakan gugatan perwakilan kelompok. Hal ini menguntungkan para pihak maupun lembaga peradilan dengan mengurangi jumlah keseluruhan litigasi dan oleh karenanya keseluruhan biaya yang dibutuhkan untuk menyelesaikan sengketa dari perilaku salah dapat dikurangi. Apabila prosedur gugatan perwakilan kelompok tidak ada, maka sebagian besar dari gugatan-gugatan yang dilitigasikan secara individual yang mengarah pada duplikasi dan proses pemeriksaan yang mahal. Akhirnya, banyak penggugat yang potensial dengan mudah melakukan joinder. Bahkan, dalam konteks Ontario, gugatan perwakilan kelompok mengumpulkan "individually recoverable claims". Hal tersebut merupakan kategori gugatan pertama class action di Ontario. Ia merupakan suatu gugatan jika the amount of the individual damage or claim is sufficiently large that the individual could bring suit on his own in the absence of class action procedure. ${ }^{9}$ Berarti hal tersebut menguntungkan baik penggugat maupun tergugat, karena gugatan itu mereduksi biaya pembelaan (defence costs) dengan mengeliminasi kebutuhan untuk melakukan pembelaan pada masing-masing gugatan individu.

${ }^{9}$ D.N. Dewees et al, Class actions as a Regulatory Instrument, Economic Council, Toronto, Ontario, 1980, hlm. 9. 
Economic efficiency itu dikaitkan dengan kasus-kasus seperti Agent range DES Asbestos, yang para pihaknya mencapai ratusan bahkan ribuan orang, telah menimbulkan beban berat bagi para pihak, pengacara dan pengadilan. Beban berat, ketidakefisienan itu muncul karena pengadilan harus melayani semua pihak untuk melakukan konsul secara individual. Dalam soal penghematan (efisiensi) peradilan ini bukan hanya didominasi oleh gugatan perwakilan kelompok, joinder juga memiliki limitasi signifikan sebagai mekanisme litigasi bagi sejumlah gugatan individu dalam suatu cara kerja tunggal. Dalam kajian yang lebih luas, penghematan peradilan dengan menggunakan gugatan perwakilan kelompok ini juga terkait dengan soal "payment of cost and legal fees" termasuk didalamnya biaya advokasi.

Kedua, berkaitan dengan akses ke pengadilan (access to the justice), bagi orangorang yang dirugikan (aggrieved person) sebagai akibat dari mass tort. Ada berbagai halangan (barriers) yang secara sosiologis dapat muncul pada orang-orang yang dirugikan untuk membawa perkaranya ke pengadilan. Halangan itu, diantaranya adalah halangan-halangan ekonomi untuk menuntut ganti rugi (economic barrier to redress), halangan-halangan psikologi, dan sosial untuk menuntut ganti rugi. ${ }^{10}$ Halangan ekonomi dapat digambarkan dalam banyak keadaan "contingency fees" (keseluruhan biaya perkara) dengan basis individu dapat melampaui nilai atau besarnya gugatan, dan jumlah minimal nilai kompensasi (compensation fund) yang diterima penggugat sendiri. Hal itulah yang kemudian menjadi pertimbangan ekonomis yang dapat dikatakan tidak rasional (not economically rational) untuk mengajukan tuntutan/gugatan. Misalnya, dalam bidang hukum pasar modal, orang Amerika mengestimasikan besarnya tuntutan yang diperlukan untuk menjamin litigasi individu; kurang lebih \$2,000, namun jika sampai ke pengadilan dapat mencapai \$10,000. Banyak lawyer di bidang pasar modal tidak akan membawa gugatan soal insider trading, kecuali besarnya gugatan minimal $\$ 100,000 .{ }^{11}$

Dalam litigasi di pengadilan Indonesia, proses persidangan memiliki beberapa tahapan persidangan. Dari pengajuan gugatan, jawaban, replik, duplik, pembuktian, pembacaan/penyampaian kesimpulan masing-masing pihak dan putusan. Bagi gugatan ganti kerugian yang nilainya sangat kecil, misalnya kerugian di bawah Rp. 10.000.000,00 (sepuluh juta rupiah), biaya perkara (contigent fees) yang harus

\footnotetext{
${ }^{10}$ Hari Purwadi, Gugatan Kelompok (Class action) dalam Tata Hukum Indonesia, Penerbit Universitas Diponegoro, Semarang, 2003, hlm. 139.

${ }^{11}$ Herlad Koch, "Non-class Group Litigation Under Eu and German Law”, dalam Journal or Comparative \& International Law, vol. II Spring/Summer 2001, hlm 366. http:/www.law.duke.edu/journal/djcil/
} 
dikeluarkan - mulai biaya pengadilan sampai honor advokat dapat mencapai separuhnya. Bahkan dapat lebih dari itu, bergantung pada jenis perkaranya dan advokat yang menanganinya. Jumlah gugatan yang jauh lebih kecil dari itu fleksibel dalam penerapan prosedur gugatan perwakilan kelompok. Dalam kasus pemadaman listrik pada 13 April 1997, besarnya ganti rugi yang diminta masingmasing penggugat pribadi sebesar Rp 964.000 (sembilan ratus enam puluh empat ribu rupiah) untuk ganti rugi materiil; dan Rp. 500.000,00 (lima ratus ribu rupiah) untuk ganti rugi immateriil, sedangkan untuk penggugat yang diwakilinya (masyarakat konsumen listrik) masing-masing hanya sebesar Rp. 164.000,00 (seratus enam puluh empat ribu rupiah) untuk ganti rugi materiil dan tidak lebih rendah dari Rp. 500.000,00 (lima ratus ribu rupiah) untuk ganti rugi immateriil. ${ }^{12}$

Di samping halangan ekonomi, terdapat juga halangan sosial yang secara efektif dapat melindungi orang-orang yang membuat kerugian (an injured person) dari tuntutan kompensasi melalui cara-cara litigasi, antara lain: 1) karena ketidaktahuan korban terhadap adanya hak-hak hukum substantif (substantive legal rights) atau lembaga-lembaga hukum yang dapat membantu menegakkan hak-hak itu; 2) efektifitas penegakan hakhak hukum yang ada, ketika kerugian-kerugian yang signifikan itu muncul tanpa diketahui oleh korban. Misalnya, dalam hal saham rata-rata investor tidak memiliki kecanggihan untuk mengetahui terjadinya pelanggaran-pelanggaran terhadap hukum pasar modal. Ketidaktahuannya itu pada kenyataannya mengakibatkan kerugian finansial. Pada efektifitas untuk menuntut gantirugi, harapannya dibentuk oleh pengalaman-pengalaman terhadap sistem peradilan yang kurang dapat dipercaya.

Ketiga, fungsi penting dari gugatan perwakilan kelompok adalah untuk mengubah perilaku yang tidak pantas (inappropriate behaviour) dari pihak tergugat. Potensi litigasi perdata untuk mengubah perilaku buruk paling nyata berkenaan dengan putusan pengadilan yang berupa perintah pada tergugat untuk melakukan atau tidak melakukan suatu perbuatan tertentu (injunctive relief). Tipe ini tidak secara langsung memberikan keuntungan uang (ganti rugi, monetory benefit) kepada para penggugat, namun lebih berwujud tekanan pada tergugat untuk mengubah perilaku mereka sesuai dengan putusan injunction dalam cara-cara yang menguntungkan para penggugat.

Proses yang berujung pada kompensasi bagi pihak yang dirugikan akhirnya dapat mempengaruhi perilaku tergugat melalui mekanisme pasar, sehingga dapat meminimalisasi kerugian pada masyarakat. Hal seperti ini sering terjadi dalam

\footnotetext{
${ }^{12}$ Berdasarkan Putusan Pengadilan Negeri Jakarta Selatan No. 134/Pdt.G/1997/PN. Jakarta Selatan.
} 
kasus-kasus pencemaran lingkungan hidup dan polusi industri. Misalnya, untuk menghindari kompensasi atas kerugian yang diderita korban atau perusakan lingkungan, maka tergugat dalam menjalankan kompensasinya dengan mengadakan instalasi-instalasi pengontrol polusi dan lain-lain. Walaupun pengadaan instalasiinstalasi itu mempengaruhi biaya produksi (cost of product), tetapi konsumen berada dalam posisi yang lebih baik.

Gugatan perwakilan kelompok memberikan kekuatan tambahan untuk perubahan perilaku yang disebabkan potensinya untuk mengatasi halanganhalangan ekonomi dalam litigasi. Tergugat yang menyebabkan kerugian itu tidak dapat digugat untuk tuntutan yang secara individual "non recoverable". Ini hanya dapat dilakukan dengan tuntutan gugatan perwakilan kelompok, karena tuntutan secara individual hanya tuntutan yang berkenaan dengan kerugian yang dapat dimintakan ganti rugi (recoverable claims) yang secara rasional dapat digugat.

Sistem beracara dengan menggunakan prosedur class action hanya dikenal di negara-negara Anglo Saxon. Di negara-negara Eropa Kontinental dikenal bentuk lain dari prosedur pengajuan gugatan yang melibatkan kepentingan sejumlah besar orang secara perwakilan. Di dalam hukum Romawi, prosedur pengajuan gugatan yang melibatkan kepentingan umum secara perwakilan, disebut actio popularis. ${ }^{13}$ Actio popularis merupakan gugatan yang dapat diajukan oleh setiap warga negara, atas nama kepentingan umum berdasarkan perbuatan melawan hukum. Dapat disimpulkan bahwa pengertian actio popularis adalah pengajuan gugatan yang dapat dilakukan oleh setiap orang terhadap adanya perbuatan melawan hukum, dengan mengatasnamakan kepentingan umum, berdasarkan peraturan perundangundangan yang mengatur adanya prosedur tersebut.

Pengertian kepentingan umum (public interest) adalah something in which the public, the community at large, has some pecuniary interest, or some interest by which their legal right or liabilities are affected. ${ }^{14}$ Ada berbagai batasan kepentingan umum dalam peraturan perundang-undangan di Indonesia. Soedikno Mertokusumo menyimpulkan bahwa yang dimaksud dengan kepentingan umum adalah kepentingan yang harus didahulukan daripada kepentingan lainnya, yang menyangkut kepentingan bangsa dan negara, pelayanan umum dalam masyarakat luas, rakyat banyak dan atau

${ }^{13}$ E. Sundari, Pengajuan Gugatan Secara Class Action (Suatu Studi Perbandingan dan Penerapannya di Indonesia), Universitas Atma Jaya, Yogyakarta, 2002, hlm. 15.

${ }^{14}$ Henry Campbell Black, Black's Law Dictionary, Sixth Edition, West Publishing Co, ST. Paul, Minn. 1990, hlm. 1229. 
pembangunan di berbagai bidang kehidupan, dengan tetap memperhatikan proporsi pentingnya dan tetap menghormati kepentingan yang lain, dimana dalam menetapkan dan memelihara kepentingan pribadi tidak boleh merugikan kepentingan umum atau masyarakat. ${ }^{15}$

Berdasarkan pengertian kepentingan umum apabila dikaitkan dengan kepentingan yang hendak dituntut dengan prosedur actio popularis dapat meliputi pelayanan umum dalam masyarakat luas. Pelayanan umum itu antara pelayanan kesehatan, keamanan, dan kedamaian masyarakat oleh pemerintah yang selama ini dianggap oleh masyarakat belum memadai, pengadaan angkutan umum, pengadaan air minum, listrik, perlindungan lingkungan, perlindungan hutan dan lain-lain. Oleh karena masalah tersebut merupakan kepentingan masyarakat luas, maka setiap orang yang pada hakekatnya adalah anggota masyarakat sangat berkepentingan untuk menuntutnya. Gugatan secara actio popularis juga dapat diajukan terhadap pihak swasta, yang ikut menyelenggarakan pelayanan umum.

Prinsip actio popularis memiliki persamaan dengan prinsip gugatan perwakilan kelompok, Keduanya sama-sama berkaitan dengan pengajuan gugatan yang melibatkan kepentingan sejumlah besar orang secara perwakilan. Perbedaannya, dalam actio popularis yang berhak mengajukan gugatan adalah setiap orang atas dasar bahwa ia adalah anggota masyarakat, tanpa ada keharusan bahwa orang tersebut merupakan pihak yang mengalami kerugian secara langsung. Dalam class action tidak setiap orang berhak mengajukannya, melainkan hanya salah satu atau beberapa orang yang merupakan anggota dari sekelompok orang yang ikut mengalami kerugian secara langsung. Kepentingan yang dituntut dalam actio popularis adalah kepentingan umum yang dianggap kepentingan setiap anggota masyarakat juga, sedangkan dalam class action kepentingan yang dituntut adalah kepentingan yang sama dalam suatu permasalahan yang menimpa kelompok tersebut. Dalam sistem common law, prinsip actio popularis ini sama dengan citizen lawsuit seperti gugatan terhadap pelanggaran perlindungan lingkungan oleh warga negara, baik terhadap warga negara yang mengalami langsung terkena pencemarannya ataupun tidak, karena masalah perlindungan lingkungan merupakan kepentingan umum atau kepentingan masyarakat luas, maka setiap warga negara berhak menuntutnya. ${ }^{16}$

\footnotetext{
${ }^{15}$ Sudikno Mertokusumo, Hukum Acara Perdata Indonesia, ed. Kelima, Liberty, Yogyakarta, 1996, hlm. 45-46.

${ }^{16}$ Mas Achmad Santosa, Konsep dan Penerapan gugatan Perwakilan (Class Action), Indonesia Center for Environmental Law (ICEL), Jakarta, 1997, hlm. 20.
} 
Di Belanda, dikenal groepacties yang mempunyai arti berbeda dengan pengertian gugatan perwakilan kelompok. Groepacties suatu pemberian hak gugat (standing) bagi suatu badan hukum untuk mewakili kepentingan orang banyak. ${ }^{17}$ Badan hukum tersebut tidak perlu merupakan bagian dari kelompok yang diwakilinya, namun cukup apabila didalam anggaran dasarnya mencantumkan perlindungan kepentingan masyarakat banyak yang diwakilinya. Gugatan perwakilan kelompok adalah masalah yang berkaitan dengan prosedur pengajuan perkara yang melibatkan sekelompok orang yang mempunyai kepentingan serta permasalahan yang sama. Kepentingan yang dituntut dalam groep acties adalah kepentingan orang banyak dalam arti kepentingan umum dan tidak boleh menuntut ganti kerugian. Kepentingan yang dituntut dalam gugatan perwakilan kelompok adalah kepentingan yang sama dari sekelompok orang yang bersifat individual, yang umumnya berupa tuntutan ganti kerugian. Badan hukum yang mengajukan tuntutan dalam groep acties tidak harus mengalami kerugian secara nyata, atau tidak harus bertempat tinggal dalam satu daerah dengan masyarakat yang diwakili.

Di Indonesia pemberian hak gugat kepada badan hukum telah mengalami perkembangan pula yaitu dengan adanya pemberian hak gugat (standing) kepada organisasi non pemerintah (non government organization). Pemberian hak gugat itu disertai dengan persyaratan organisasi non pemerintah tersebut berbentuk badan hukum dan didalam Anggaran Dasarnya mencantumkan kegiatan yang sama dengan yang diperjuangkan di pengadilan. Beberapa kasus seperti kasus perlindungan konsumen dan pelestarian lingkungan adalah kasus publik, yaitu kasus yang menyangkut kepentingan masyarakat luas. Banyaknya kasus-kasus publik yang muncul mendorong organisasi-organisasi advokasi, seperti: Sierra Club Defense Fund di Amerika Serikat, Polution Probe di Canada, Environmental Defenders Office di Australia, dan Yayasan Lembaga Bantuan Hukum Indonesia (YLBHI), Yayasan Lembaga Konsumen Indonesia (YLKI) serta Wahana Lingkungan Hidup Indonesia (Walhi) di Indonesia. Selain untuk memperjuangkan kepentingan masyarakat, organisasiorganisasi tersebut terbukti sangat efektif dalam mendorong pembaruan kebijaksanaan, mengubah sikap juga perilaku birokrasi dan pengusaha melalui tekanan-tekanan yang dilakukan dalam bidang advokasi. Dalam rangka memperjuangkan misinya, organisasi-organisasi tersebut umumnya tidak

${ }_{17}$ Paulus Efendi Lotulung, Penegakan Hukum Lingkungan Oleh Hakim Perdata, Citra Aditya Bakti, Bandung, 1993, hlm. 53. 
mempunyai kepentingan hukum, dalam arti tidak mempunyai kepentingan pemilikan (propiertary) maupun kepentingan ekonomis.

Di sisi lain, untuk kepentingan masyarakat maupun lingkungan perlu diadakan suatu pengakuan hukum (legal recognition) yang memberikan peluang pada suatu organisasi untuk mengajukan gugatan. Peluang seperti ini sulit diperoleh di negara yang menganut sistem hukum civil law, karena doktrin hukum perdata yang dianut sistem hukum ini menyaratkan adanya kepentingan hukum untuk dapat mengambil bagian di pengadilan sebagai penggugat. Dalam kasus yang menyangkut sumber daya alam, objek sumber daya alam (sungai, hutan, dan mineral atau tambang) yang pada umumnya dikuasai oleh negara, membawa konsekuensi bahwa sifat berkelanjutan sumber daya alam lebih banyak ditentukan dan bergantung pada konsekuensi, aktivisme, dan keberanian pemerintah sebagai aparatur negara.

Dalam kenyataannya, seringkali pemerintah mengabaikan kewajibannya untuk melestarikan sumber daya alam. Pemerintah antara lain tidak menerapkan perijinan atau menjalankan fungsi pengawasan sebagaimana yang telah ditentukan oleh peraturan perundang-undangan. Keadaan semacam ini mengkibatkan kelompokkelompok masyarakat seperti LSM melakukan tindakan korektif, melalui jalur hukum. Agar tindakan korektif tersebut dapat dilakukan secara efektif, diperlukan penyediaan akses LSM ke pengadilan melalui pengembangan standing.

Hak standing tidak secara otomatis menjamin keberhasilan litigasi kasus-kasus publik, karena pada dasarnya standing hanyalah merupakan "tiket masuk" ke dalam arena advokasi hukum (legal battle) yang sarat dengan berbagai kendala. Kendala itu antara lain berkaitan dengan kendala pembuktian, perangkat pemulihan, (remedial tools) yang tersedia, sampai pada kendala yang berkaitan dengan kesiapan majelis hakim dalam memberikan putusan terbaik. Oleh karena itu, pengembangan konsep standing sebagai salah satu hak prosedural dalam litigasi prosedural mutlak dilakukan. Hak-hak prosedural tersebut diantaranya adalah hak masyarakat atau pencari keadilan untuk mendapatkan akses pada saksi ahli, akses informasi, ketersediaan remedial tools yang memadai dalam gugatan perdata dan pengembangan sistem pertanggungjawaban strict liability. ${ }^{18}$

${ }^{18}$ Strict Liability adalah suatu doktrin pertanggungjawaban perdata dibidang lingkungan hidup diamana tanggung jawab muncul seketika dan tidak harus berdasarkan pada kesalahan (liability without fault). Kajian mendalam tentang: Strict Liability baca: Mas Achmad Sentosa, "Penerapan Asas Tanggung Jawab Mutlak (Strict Liability) Dibidang Lingkungan Hidup.” Jurnal ICEL, ke II, 1997, hlm. 3 


\section{Distribusi Ganti Rugi}

Gugatan perwakilan pada dasarnya adalah gugatan perdata, yakni gugatan perbuatan melawan hukum yang dikaitkan dengan Pasal 1365 Kitab Undang-Undang Hukum Perdata (KUHPerdata). Perbuatan melawan hukum di Indonesia secara normatif merujuk pada Pasal 1365 KUHPerdata. Ketentuan dalam pasal ini lebih merupakan struktur norma daripada substansi. Oleh karenanya ketentuan ini senantiasa memerlukan materialisasi di luar ketentuan Pasal 1365 KUHPerdata. ${ }^{19}$ Pasal tersebut menentukan kewajiban pelaku perbuatan untuk membayar ganti rugi, tetapi diatur lebih lanjut mengenai ganti rugi tersebut. Mariam Darus Badrulzaman mengatakan bahwa undang-undang lengkap mengatur ganti rugi dalam perbuatan melawan hukum. Oleh karena itu, ketentuan ganti rugi dalam wanprestasi dalam Pasal 1243 - 1252 KUHPerdata diterapkan ke dalam perbuatan melawan hukum secara analogis. ${ }^{20}$

Penyelesaian ganti rugi dilakukan setelah pertanggungjawaban ada dalam pertimbangan putusan hakim. Pada dasarnya pelaksanaan ganti rugi merupakan eksekusi putusan terhadap gugatan perwakilan kelompok yang dikabulkan pengadilan dan berkekuatan hukum tetap. Dalam hukum acara, eksekusi putusan pengadilan dilaksanakan oleh ketua pengadilan negeri atas permohonan pihak yang menang.

Pelaksanaan ganti rugi akan menimbulkan kesulitan, jika dalam amar putusan pengadilan tidak menunjuk tim atau panel untuk membantu kelancaran pendistribusian ganti rugi. Tim atau panel tersebut dengan koordinasi panitera pengadilan negeri yang secara administratif akan mengelola pendistribusian ganti rugi.

Di Australia, pelaksanaan ganti rugi biasanya diserahkan kepada para pihak untuk melakukan perundingan sendiri dalam jangka waktu yang ditentukan hakim. Hasilnya harus dilaporkan kepada hakim dalam persidangan yang terbuka untuk umum. ${ }^{21}$ Untuk kondisi Indonesia, dengan biaya perkara yang rendah, penyelesaian ganti rugi ini akan menimbulkan kesulitan, para pihak umumnya enggan berdamai dan perkara tersebut akan berlanjut sampai tingkat kasasi. Berbeda dengan kondisi

\footnotetext{
${ }^{19}$ Rosa Agustina, Perbuatan Melawan Hukum, Universitas Indonesia Fakultas Hukum Pascasarjana, Jakarta, 2003, hlm. 3 .

${ }^{20}$ Mariam Darus Badrulzaman, KUHPerdata, Buku III, Hukum Perikatan Dengan Penjelasan, Alumni, Bandung, 1983, hlm. 148.

${ }^{21}$ Susanti Adi Nugroho, Op. Cit., hlm. 67.
} 
Indonesia, di Amerika Serikat, jika penggugat berhasil memberikan bukti-bukti yang kuat, dan untuk menghindari bertambahnya biaya perkara yang mahal, tergugat lebih menyukai penyelesaian dengan berdamai.

Pendistribusian ganti rugi merupakan tahapan akhir dari prosedur gugatan perwakilan kelompok. Meskipun tahapan penyelesaian ganti rugi ini hanya bersifat administratif, tetapi persoalannya tidak dapat dianggap ringan. Ini berkaitan dengan masalah uang atau dana yang dapat memicu perpecahan. Ganti rugi dapat dibagikan kepada anggota kelas atau sub kelas setelah dilakukan notifikasi.

Penentuan ganti rugi dapat ditetapkan secara spesifik kepada setiap anggota kelas atau sub kelas atau individu tertentu atau dapat ditentukan dapat ditetapkan suatu jumlah keseluruhan secara bersama-sama. Anggota kelas atau sub kelas dapat mengambil ganti rugi dengan mengisi formulir permohonan dan menyerahkan bukti-bukti bahwa dirinya juga adalah korban. Hal ini untuk mencegah pemberian ganti rugi kepada yang tidak berhak. Putusan hakim juga dapat mencantumkan cara anggota kelas melakukan klaim dan cara penyelesaiannya jika terdapat perbedaan dalam melakukan klaim ganti rugi. ${ }^{22}$

Bagaimana jika anggota kelas yang pada notifikasi pertama tidak opt-out, pada taraf pembagian ganti rugi tidak mau menerima karena kemungkinan dianggap terlalu kecil jika dibandingkan dengan kerugian nyata yang diderita ? Di Amerika Serikat, anggota kelas yang mengajukan opt-out pada awal notifikasi, pada taraf penyelesaian ganti rugi tidak dapat lagi mengajukan keberatan dengan opt-out. Ia juga terikat putusan gugatan perwakilan tersebut. Sebaliknya, dapat juga terjadi mereka yang opt-out pada awal notifikasi, pada taraf penyelesaian ganti rugi dengan memberikan bukti daripada mengajukan gugatan sendiri.

Di Australia, yang hal yang terakhir itu dapat dikabulkan jika disetujui oleh tergugat demi tuntasnya perkara. Masalah-masalah ini dapat diselesaikan oleh panel, jika di dalam petitum gugatan juga dimohonkan untuk dibentuk suatu tim atau panel. Administrasi pelaksanaan ganti rugi tidak diatur secara eksplisit. Di dalam praktik, pengadilan akan menetapkan suatu mekanisme yang paling praktis untuk mengadministrasikan dan mendistribusikan uang ganti rugi tersebut, termasuk bunga yang diperoleh dari uang ganti rugi tersebut. Biasanya pengadilan menetapkan suatu panel untuk melaksanakan administrasi penyelesaian ganti rugi.

\footnotetext{
${ }^{22}$ Mas Achmad Santoso, Konsep dan Penerapan Gugatan Perwakilan (Class Action), Indonesian Center for Environmental Law (ICEL), Jakarta, 1997, hlm. 33.
} 
Hal in tidak diatur dalam AFCA, tetapi dalam praktik sangat didukung oleh pengadilan. Mekanisme pengelolaan dana yang berasal dari pembayaran ganti rugi dan pendistribusian dana kepada yang berhak juga dilakukan dengan mendirikan Fund. ${ }^{23}$ Fund adalah lembaga internasional independen yang memiliki berbagai sumber dari berbagai pihak dan bertujuan sosial dalam pelayanan jasa perlindungan hukum dan kepentingan umum.

Dalam praktik di Amerika Serikat disamping ditunjuk panel yang terdiri dari perwakilan keduabelah pihak, pendistribusian dapat dilakukan oleh master biasanya adalah seorang akuntan. Seluruh proses pengadministrasian ganti rugi di bawah pengawasan hakim yang memeriksa perkara. Apakah hal ini dapat dilakukan di Indonesia ? Permasalahan ini diajukan mengingat pelaksanaan putusan hakim adalah wewenang ketua pengadilan negeri yang tidak selalu menjadi hakim yang menyidangkan perkara tersebut. Untuk memudahkan pengadilan melakukan eksekusi putusan jika gugatan dikabulkan, penunjukkan suatu panel yang disebutkan sejak awal dalam surat gugatan adalah mutlak. ${ }^{24}$

Ada kemungkinan masih ada sisa ganti rugi atau ada bunga bank dari ganti rugi. Mengenai hal ini Perma tidak mengaturnya. Di Amerika Serikat, dalam hal ada sisi, sisa tersebut diberikan kepada yayasan sosial atau keperluan lain yang mendekati tujuan gugatan asal. Dalam menentukan yayasan sosial penerima sisa tersebut didasarkan pada diskresi hakim. Jadi, peran hakim sangat menentukan. ${ }^{25}$ Di Australia, sisa tersebut diminta kembali oleh tergugat. Sehubungan dengan ini Pasal 33 Z (5) Representative Proceedings, Federal Court of Australia Act menyatakan: "On application by the respondent in the representative proceeding after the day foxed under paragraph (3) (d), the court may take such orders as are just for the payment from the fund to the respondent of the money remaining in the fund". Gagasan untuk memanfaatkan sisa ganti rugi untuk kepentingan publik yang masih ada kaitannya dengan objek gugatan tidak diatur dalam Australia Federal Court Act. Jika jumlah dana ganti tidak mencukupi karena perusahaan pailit, anggota kelas dalam perkara tersebut tidak dimungkinkan opt-out agar ganti rugi dapat dibagi rata.

Dalam praktik gugatan perdata biasa, biaya perkara untuk mengajukan gugatan dan biaya lain yang timbul gugatan tersebut seperti biaya pemanggilan saksi, saksi

\footnotetext{
${ }^{23}$ Ibid., hlm. 34.

${ }^{24}$ Susanti Adi Nugroho, Op. Cit., hlm. 69 -70.

${ }^{25}$ Ibid., hlm. 71.
} 
ahli, sita jaminan jika ada, ditanggung terlebih dahulu oleh penggugat. Biaya-biaya tersebut pada akhirnya akan dibebankan kepada pihak yang kalah dalam berperkara. Oleh karena Perma tidak mengatur hal itu, maka perkara gugatan perwakilan kelompok dapat mengacu kepada gugatan biasa. Biaya-biaya perkara, termasuk biaya notifikasi oleh penggugat atau wakil kelompok. Wakil kelompok menanggung risiko membayar biaya perkara yang timbul dari gugatan dimaksud. Jika gugatan perwakilan kelompok ditolak hakim. Anggota kelas tidak dibebani untuk membayar untuk membayar biaya yang timbul dari gugatan perwakilan kelompok tersebut, kecuali dengan sukarela ikut membantu biaya-biaya itu.

Dengan demikian, pemilihan wakil kelas harus dilakukan secara hati-hati dan wakil kelas disamping memiliki bukti-bukti yang paling kuat juga mampu menanggulangi biaya-biaya yang timbul. Jika gugatan perwakilan kelompok ini dikabulkan, biaya-biaya yang telah dikeluarkan oleh wakil kelas dapat lebih dahulu dengan ganti rugi yang diperoleh, sebelum dibagikan kepada seluruh anggota kelas. Pada umumnya wakil kelas dalam kelompok memperoleh ganti rugi lebih besar daripada anggota kelompoknya.

Di negara-negara lain, juga dianut asas pihak yang kalah membayar biaya-biaya pihak yang menang, bahkan termasuk biaya pengacara yang menang. Di Indonesia, dalam praktik peradilan, masalah seperti ini tidak pernah dikabulkan, meskipun hal tersebut dimohon oleh salah satu pihak. Alasannya, di Indonesia tidak ada keharusan untuk berperkara dengan menggunakan jasa pengacara. ${ }^{26}$

Di Australia, masalah biaya perkara ini menimbulkan kontroversi publik karena tidak adil jika gugatan perwakilan kelompok tidak dikabulkan, wakil kelas harus membayar biaya perkara yang mahal, karena umumnya wakil kelas memiliki keuangan yang terbatas. Oleh karena itu, gugatan perwakilan kelompok di Australia umumnya diwakili oleh kantor pengacara khusus gugatan perwakilan kelompok yang bersedia berspekulasi menanggung segala kerugian atas kegagalan gugatan. Di Amerika Serikat, pengacara gugatan perwakilan kelompok menerima bagian yang sangat besar jika gugatannya dikabulkan pengadilan. Di Australia, biaya pengacara tidak dapat didasarkan pada bagian dari ganti rugi, tetapi dibayar berdasarkan jumlah kehadirannya (worked performed). Oleh karena itu, di Australia juga timbul gagasan cost shifting yang mengusulkan agar pemerintah commonwealth mendirikan

\footnotetext{
${ }^{26}$ Ibid., hlm. 72.
} 
fund yang menyediakan dana untuk membiayai wakil kelas yang mengajukan gugatan perwakilan kelompok. ${ }^{27}$

Pasal 9 Perma menentukan bahwa dalam hal gugatan ganti rugi dikabulkan, hakim memutuskan (1) jumlah ganti rugi secara rinci; (2) penentuan kelompok dan/ atau sub kelompok yang berhak; (3) mekanisme pendistribusian ganti rugi; dan (4) langkah-langkah yang wajib ditempuh oleh kelompok dalam proses penetapan dan pendistribusian atau notifikasi.

Perma tidak memberikan penjelasan bagaimana bentuk putusan yang berkaitan dengan gugatan perwakilan kelompok. Di Australia, penyelesaian ganti rugi dirundingkan para pihak dalam jangka waktu yang ditentukan oleh hakim dan hasilnya dilaporkan kepada hakim dalam sidang terbuka untuk umum. Di Amerika Serikat, disamping ditunjuk panel yang terdiri dari perwakilan keduabelah pihak, seluruh proses pendistribusian dan administrasi ganti rugi selalu di bawah pengawasan hakim yang memeriksa perkara yang bersangkutan. Susanti Adi Nogroho berpendapat dengan mengacu Pasal 10 Perma, diktum putusan hakim sama dengan putusan perkara perdata biasa, hanya saja lebih rinci menetapkan bagian ganti rugi bagi anggota kelompok atau sub kelompok. Termasuk juga bagaimana mekanisme pembayaran ganti rugi kepada anggota kelompok yang jumlahnya banyak. ${ }^{28}$ Perlu diperhatikan bahwa diktum putusan hakim tidak boleh mengabulkan atau melebihi apa yang dimohon. Oleh karena itu, penelitian atas surat gugatan perwakilan kelompok yang masuk sebelum deregister sangat penting agar tidak menimbulkan kesulitan jika kelak gugatan dikabulkan. Persayaratan yang ditentukan Pasal 3 sub f Perma benar-benar diperhatikan.

\section{Penutup}

Berdasarkan analisis terhadap tinjauan pustaka, kasus-kasus serta wawancara dengan para narasumber maka dari permasalahan yang ada dapat diambil kesimpulan sebagai berikut:

Gugatan perwakilan kelompok memberikan kekuatan tambahan untuk perubahan perilaku yang disebabkan potensinya untuk mengatasi halanganhalangan ekonomi dalam litigasi. Tergugat yang menyebabkan kerugian itu tidak

\footnotetext{
${ }^{27}$ Ibid.

${ }^{28}$ Ibid., hlm. 54.
} 
dapat digugat untuk tuntutan yang secara individual "non recoverable". Ini hanya dapat dilakukan dengan tuntutan gugatan perwakilan kelompok, karena tuntutan secara individual hanya tuntutan yang berkenaan dengan kerugian yang dapat dimintakan ganti rugi (recoverable claims) yang secara rasional dapat digugat.

Prosedur penyelesaian sengketa yang berkaitan dengan ganti rugi perbuatan melawan hukum dalam class action bahwa penggugat mengenai ganti rugi harus dikemukakan secara rinci, harus memuat usulan tentang mekanisme atau tata cara pendistribusian ganti kerugian kepada keseluruhan anggota kelompok termasuk usulan tentang pembuktian atau panel yang membantu memperlancar pendistribusian ganti kerugian. Jika tuntutan ganti kerugian dikabulkan, hakim wajib memutuskan jumlah ganti rugi secara rinci, penentuan kelompok, mekanisme pendistribusian ganti rugi dan langkah-langkah yang wajib ditempuh oleh wakil kelompok seperti halnya kewajiban melakukan pemberitahuan atau notifikasi.

\section{Daftar Pustaka}

Adi Nugroho, Susanti, Pedoman Prosedur Gugatan Perwakilan Kelompok (Class Actions) di Indonesia, Kapuslitbang Hukum dan Peradilan Mahkamah Agung RI

Black, Henry Campbell, Black's Law Dictionary, West Publishing Co., Saint Paul Minn, 1990.

E., Sundari, Pengajuan Gugatan Secara Class Action (Suatu Studi Perbandingan dan Penerapannya di Indonesia), Universitas Atma Jaya, Yogyakarta, 2002.

Hartono, Sunarjati C.F.G. Penelitian Hukum di Indonesia pada Akhir Abad Ke 20, Alumni, Bandung, 1994.

Koch, herald, "Non Class Group Litigation under Eu and German Law", dalam Duke Journal of Comporative E International Law, Vol. 11 No. 2 Spring/Summer, http:/ www.Law.duke.edu/journal/djcil, 2001.

Lotulung, Paulus Efendie, Keynote Speech Lokakarya Acara Gugatan Perwakilan Kelompok (Class Action), Bogor, 27 Juli 2002.

, Penegakan Hukum Lingkungan Dalam Undang-Undang No.23 Tahun 1997 Ditinjau Dari Aspek Hukum Perdata, Indonesian Center for Environmental Law (ICEL), Jakarta, 1998.

Mertokusumo, Sudikno, Hukum Acara Perdata Indonesia, Penerbit Liberty, 1996.

Rawls, John A., Theory of Justice, Oxford University, New York, 1976.

Santosa, Mas Achmad et al, Pedoman Penggunaan Gugatan Perwakilan (Class Actions), Indonesian Center for Environmental Law (ICEL), Jakarta, 1999. 
, Penerapan Asas Tanggung Jawab Mutlak (Strict Liability) Dibidang Lingkungan Hidup, Indonesian Center for Environmental Law (ICEL), Jakarta, 1997.

Santosa, Mas Achmad, Good Governance Hukum Lingkungan, Indonesian Center for Environmental Law (ICEL), Jakarta, 2001.

, Konsep dan Penerapan Gugatan Perwakilan (Class Action), Indonesian Center for Environmental Law (ICEL), Jakarta, 1997.

, Prosedur Acara Gugatan Class Action Menurut Perma No.1 Tahun 2002, Bogor, 27 Juli 2002.

, Fungsi Hukum dan Perubahan Sosial, PT.Citra Aditya Bakti, Bandung,

Purwadi, Hari, Gugatan Kelompok (Class action) dalam Tata Hukum Indonesia, Penerbit Universitas Diponegoro, Semarang, 2003. 